\title{
ACE Gene Polymorphism Frequency in Steroid Resistance and Steroid Sensitive in Patients with Idiopathic Nephrotic Syndrome
}

\author{
Hussam Ahmed El-Gayar ${ }^{1}$, Faeza El-Dahtory ${ }^{2}$, Ezz El-Gamal ${ }^{3}$, Sahar Hamed ${ }^{4}$ \\ ${ }^{1,3,4}$ Urology \& Nephrology Center, Mansoura University, Egypt \\ ${ }^{2}$ Mansoura University Children Hospital, Genetic Unit, Mansoura University, Mansoura, Egypt
}

\begin{abstract}
Background: The angiotensin I-converting enzyme (ACE) gene insertion/deletion (I/D) polymorphism has been suggested as a modifier factor in benign renal diseases. However, the direct evidence from genetic association studies in adult Egyptian patients with idiopathic nephrotic syndrome remains inconclusive. Therefore, the present study aimed to investigate the frequency of ACE gene polymorphism I/D alleles, DD and II genotypes in Egyptian adult nephrotic patients and its association to their steroid response. Methods: One hundred and ninety-eight adult patients older than 19 years of age with idiopathic nephrotic syndrome were enrolled in this study. Another 102 healthy adults with no history of kidney disease volunteered were participate. The distribution frequencies of the DD, ID, II genotypes were determined were determined using a PCR method. Results: The frequency of ACE gene polymorphism Dallele and DD genotypes were significantly higher in steroid responsive adult patients with idiopathic nephrotic syndrome compared with healthy control. In contrast, the frequency of polymorphism I allele and the heterozygous of ID genotype were significantly lower in steroid responsive adult patients idiopathic nephrotic syndrome compared with healthy control. Finally, the frequency of II genotype was not significantly different between the steroid resistance, steroid sensitive and control groups. Conclusions: These findings suggest that the D allele or DD homozygous genotype could be significant genetic markers for the development of steroid response in adult Egyptian patients with idiopathic nephrotic syndrome.
\end{abstract}

Keywords: Idiopathic nephrotic syndrome, angiotensin converting enzyme (ACE), gene polymorphism, steroid resistant, steroid sensitive

\section{Introduction}

The characteristic features of idiopathic nephrotic syndrome are heavy proteinuria, hyperlipidemia, edema, and hypoalbuminia [1] where idiopathic nephrotic syndrome is one of the most frequent nephrotic syndromes. Two types of idiopathic nephrotic syndrome can be described according to the response to corticosteroids, steroid sensitive and steroid resistant. Steroid response either sensitive or resistant is the major prognostic marker of idiopathic nephrotic syndrome. The steroid sensitive patients carry good prognosis while steroid resistant patients tend to progress to end stage renal disease. Elevation of angiotensin II level may contribute to the renal injury via its ability to induce glomerular hypertension, tubular injury, myofibroblasts formation and stimulate the production of the profibrotic cytokine TGF- $\beta$. Additionally, it may induce oxidative stress and stimulates chemokines and osteopontin production that cause cell proliferation and hypertrophy [2].

The pathogenesis of angiotensin II effects on the transglomerular passage of protein includes modulation of efferent arterioler tone, inter-glomerular pressure and glomerular plasma flow [3], [4]. The presence of functional receptors for angiotensin II on glomerular podocytes may directly contribute to the pathogenesis of proteinuria via increased expression of the podocyte slit protein nephrin [5]. Moreover, Eisenbach et al., [6] reported that proteinuria in rats induced with administration of angiotensin II. Recently, angiotensin receptor blockers and angiotensin converting enzyme (ACE) inhibitors with steroids have been shown to be significantly decrease the level of proteinuria and slow the progression of renal insufficiency in patients with idiopathic nephrotic syndrome [7]. ACE levels were correlated with angiotensin II levels.

Recently, there is a growing body of evidence of the impact of genetic variability on the development of renal failure disease and emphasized the need to elucidate the genetic basis for renal diseases and its complications. The ACE gene polymorphism has insertion/deletion (I/D) genotype, defined by the presence or absence of the 287-base-pair Alu repetitive sequences in interon 16 . Importantly, the ACE levels are highest in individuals with the DD genotype and lowest with the II genotype [8].

The ACE gene I/D polymorphism are reportedly associated with the progression of different renal diseases such as diabetic nephropathy, IgA nephropathy, autosomal dominant polycystic kidney disease, and graft failure in renal transplant recipients [9], [10]. The D allele has a dominant effect and is associated with higher plasma ACE and angiotensin II levels [11], [12]. Research in genetics and genome sequencing has led to a better understanding of the molecular genetic mechanisms and to the detection of interindividual genetic differences, so-called polymorphisms, which may have a functional consequence on the response to drugs. Therefore, we aimed in the present study to investigate the frequency of angiotensin converting enzyme ACE gene polymorphism (I/D) in adult Egyptian patients with idiopathic nephrotic syndrome and its association to steroid medication response. 


\section{International Journal of Science and Research (IJSR) \\ ISSN (Online): 2319-7064}

Index Copernicus Value (2013): 6.14 | Impact Factor (2015): 6.391

\section{Materials and Methods}

\subsection{Patients Selection}

This study was approved by the ethical guidelines of Mansoura University and performed on 198 Egyptian patients with idiopathic nephrotic syndrome from outpatients clinical of Mansoura University Hospitals. The patients were grouped according to initial steroid response; the steroid-sensitive nephrotic syndrome (SS) group consisted of 104 patients who were initially steroid responsive with mean age $30.63 \pm 6.99$ years ranging from 19.0- 46.0 years and the steroid resistant nephrotic syndrome group (SR) consisted of 94 patients who maintained on cyclosporin treatments with mean age $32.54 \pm 5.87$ years ranging from 21.0- 49.0 years. None of the patients had received ACE inhibitors during treatment. The control group consisted of 102 unrelated healthy adult volunteers with mean age $27.89 \pm 5.39$ years ranging between 20 - 45 years. They are without hypertension, renal or cardiac disease or a family history of renal disease. These controls were negative for $\mathrm{HIV}, \mathrm{HCV}$ and HBV. All subjects were of Egyptian genetic origin. Three $\mathrm{ml}$ peripheral blood were collected in a tube containing EDTA solution, $\mathrm{pH} 8.0$ as an anticoagulant and DNA was extracted, purified, amplified and analyzed.

\subsection{Genotyping of the ACE Gene I/D polymorphism}

Genomic DNA was extracted from $300 \mu$ of whole blood using Promega DNA extraction kit (USA). The I/D polymorphism of the ACE gene was determined according to the method of Rigat et al., [13]. The sequences of the sense and antisense primers were 5'-CTG GAG ACC ACT CCC ATC CTT TCT-3' and 5'-GAT GTG GCC ATC ACA TTC GTC AGA T-3', respectively (prepared by eurofins, genomics, Germany). PCR was performed in a final volume of $50 \mu \mathrm{l}$ that contained $25 \mu \mathrm{l}$ master mix, $\approx 500 \mathrm{ng}$ of genomic DNA, $12.5 \mathrm{pmol}$ of each primer and $5 \%$ dimethylsulphoxide (DMSO). Amplification was performed using a Gene Amp PCR system (Thermo Scientific ARKTIK thermal cycler). Samples were denatured for 7 minute at $94^{\circ} \mathrm{C}$ and then cycled 30 times through the following steps: 45 seconds at $94^{\circ} \mathrm{C}, 1$ minute at $62^{\circ} \mathrm{C}$, and 1 minute at $72^{\circ} \mathrm{C}$. PCR products (490-bp insertion and 190-bp deletion) were visualized on a $1.5 \%$ agarose- gel containing GelStar $^{\mathrm{TM}}$ Nucleic Acid Gel Stain (LONZA, Rockland, ME, USA, Cat No: 50535) (Figure 1). A second PCR amplification was performed for each DD type with a primer pair that recognises an insertion-specific sequence (5'- TGG GAC CAC AGC GCC CGC CAC TAC-3'; 5'-TCG CCA GCC CTC CCA TGC CCA TAA-3'), with identical PCR conditions except for an annealing temperature of $67^{\circ} \mathrm{C}$ and the absence of 5\% DMSO (Figure 2).

\subsection{Statistics}

Statistical analyses were performed using the SPSS 17 for Windows software package (Chicago, Illiniois, USA). Allele and genotypic frequency was calculated by direct gene counting method. Comparison of the different genotypes was done by using Chi square test. Odd's ratios were calculated with a $95 \%$ confidence interval limit. Statistically significant accepted value was $\mathrm{p}<0.05$.

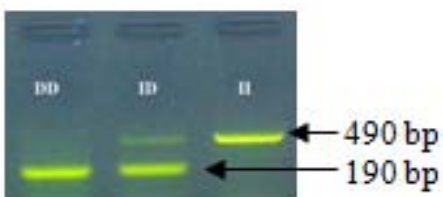

Figure 1: Agarose gel electrophoresis of the first PCR product determining the ACE genotypes. The figure shows different patients genotypes which representative by $1.5 \%$ agarose gel stained with GelStar ${ }^{\mathrm{TM}}$ Nucleic Acid Gel Stain and photographed under ultraviolet trans-illumination after PCR amplification with specific primers. The upper band of $490 \mathrm{bp}$ is the I allele and the lower band of $190 \mathrm{bp}$ is the D allele (arrows). The II genotype is shown as a single upper band, the DD genotype as a single lower band, and the DI type as a double band.

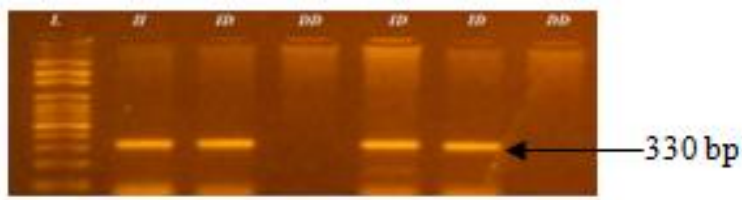

Figure 2: Agarose gel electrophoresis of the second PCR product. It shows the results of different samples from the $1^{\text {st }}$ PCR identified as DD genotype using an insertion-specific primer to differentiate if it is real DD or mis-genotype from ID. The sample in lane 1 is the Ladder, in lane 2 is a standard for II and that in lane 3 is a standard for DI were previously identified by $1^{\text {st }} \mathrm{PCR}$, followed by four samples (lanes 4 through 7) identified as DD with the insertionspanning primer. A DI sample previously misclassified as DD is in lane 5, 6 .

\section{Results}

PCR analysis demonstrated that the frequency of the ACE gene D-allele polymorphism in steroid resistance and steroid sensitive was more prominent compared to control group but was significantly increased only in steroid resistance compared to control group $(\mathrm{P}<0.006)$, while there was no significant difference between steroid resistance and steroid sensitive groups $(\mathrm{P}>0.157)$ (Table 1). In contrast, the frequency of the ACE gene I allele polymorphism in steroid resistance and steroid sensitive was a lower compared to control group but this difference was significant in only in steroid resistance group compared to control $(\mathrm{P}<0.006)$ and there was no significant difference between steroid resistance and steroid sensitive groups ( $\mathrm{P}>0.157)$, (Table 1, Figure 3). 


\section{International Journal of Science and Research (IJSR) \\ ISSN (Online): 2319-7064}

Index Copernicus Value (2013): 6.14 | Impact Factor (2015): 6.391

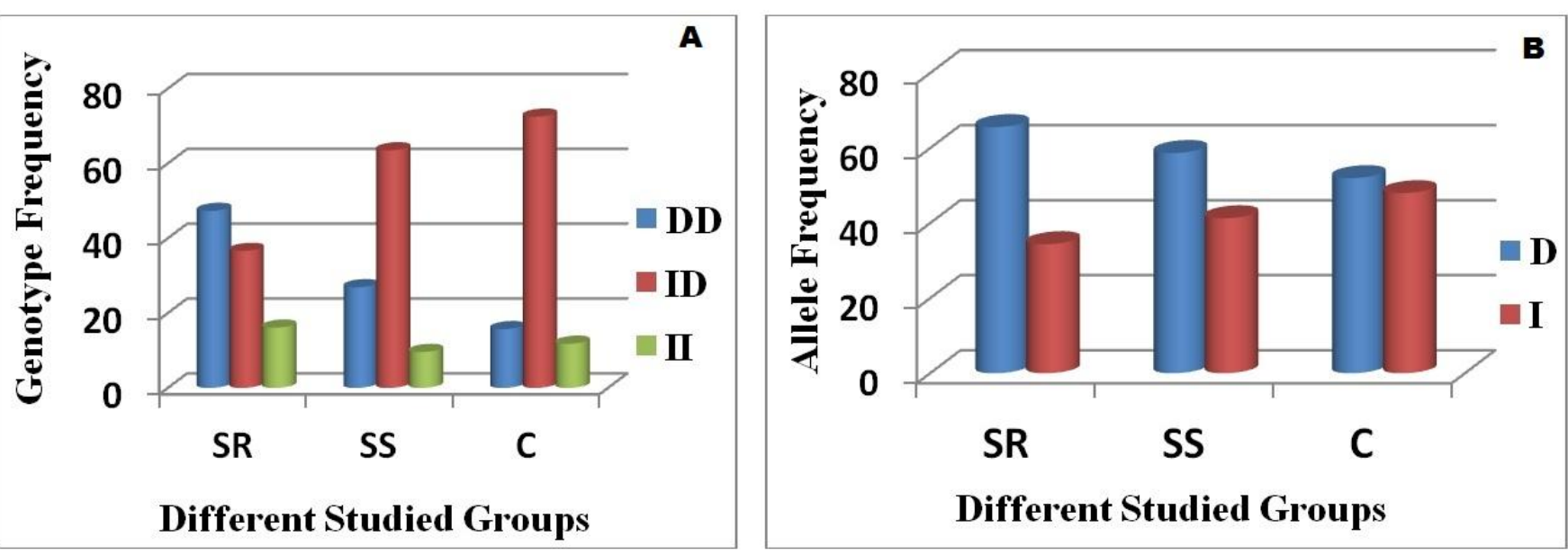

Figure 3: Distribution of genotype (A) and allele (B) frequency in the three studied groups, steroid resistance (SR), steroid sensitive (SS) patients and controls (C).

Interestingly, the frequency of the ACE gene DD polymorphism observed in both steroid resistance and steroid sensitive was higher when compared to control group but this higher was only significant in steroid resistance group $(\mathrm{P}<0.001)$ moreover, this frequency also observed in steroid resistance was significantly higher compared to steroid sensitive group $(\mathrm{P}<0.003)$ (Table 1). On the other hand, the heterozygous of ID genotype frequency was significantly lower in steroid resistance when compared to both steroid sensitive and control group $(\mathrm{P}<0.001)$, while there was no significant difference between steroid sensitive and control groups $(\mathrm{P}>0.162)$ (Table 1).

Finally, the frequency of II genotype was not significantly different between the steroid resistance, steroid sensitive and control groups (Figure 3).

Table 1: Distribution of allele and genotype frequency in the three studied groups, steroid resistance (SR), steroid sensitive (SS) patients and controls.

\begin{tabular}{|c|c|c|c|c|c|c|c|}
\hline & $\begin{array}{c}\text { SR } \\
(n=93)\end{array}$ & $\begin{array}{c}\text { SS } \\
(n=104)\end{array}$ & $\begin{array}{l}\text { Control } \\
(n=102)\end{array}$ & P- & $\mathrm{X}^{2}$ & OR $(95 \%)$ & OR (Range) \\
\hline \multicolumn{8}{|c|}{ ACE-I/D polymorphism allele frequency } \\
\hline \multirow[t]{3}{*}{$\mathrm{D}$} & $122(65.6 \%)$ & $122(58.7 \%)$ & $106(52.0 \%)$ & 0.006 & 7.444 & 1.762 & $(1.171-2.652)^{\mathrm{a}}$ \\
\hline & & & & 0.172 & 1.867 & 1.312 & $(0.889-1.936)^{b}$ \\
\hline & & & & 0.157 & 2.004 & 1.344 & $(0.892-2.024)^{\mathrm{c}}$ \\
\hline \multirow[t]{3}{*}{ I } & $64(34.4 \%)$ & $86(41.3 \%)$ & $98(48.0 \%)$ & 0.006 & 7.444 & 0.567 & $(0.377-0.854)^{\mathrm{a}}$ \\
\hline & & & & 0.172 & 1.867 & 0.762 & $(0.517-1.125)^{b}$ \\
\hline & & & & 0.157 & 2.004 & 0.744 & $(0.434-1.121)^{\mathrm{c}}$ \\
\hline \multicolumn{8}{|c|}{ Genotype frequency } \\
\hline \multirow[t]{3}{*}{$\mathrm{DD}$} & $44(47.3 \%)$ & $28(26.9 \%)$ & $16(15.7 \%)$ & 0.001 & 22.841 & 4.827 & $(2.467-9.443)^{\mathrm{a}}$ \\
\hline & & & & 0.049 & 3.871 & 1.980 & $(0.996-3.938)^{b}$ \\
\hline & & & & 0.003 & 8.801 & 2.437 & $(1.345-4.417)^{\mathrm{c}}$ \\
\hline \multirow[t]{3}{*}{ ID } & $34(36.6 \%)$ & $66(63.5 \%)$ & $74(72.5 \%)$ & 0.001 & 25.50 & 4.586 & $(2.502-8.407)^{\mathrm{a}}$ \\
\hline & & & & 0.162 & 1.953 & 1.522 & $(0.843-2.746)^{b}$ \\
\hline & & & & 0.001 & 14.217 & 3.014 & $(1.608-5.368)^{\mathrm{c}}$ \\
\hline \multirow[t]{3}{*}{ II } & $15(16.1 \%)$ & $10(9.6 \%)$ & $12(11.8 \%)$ & .378 & 0.777 & 1.442 & $(0.637-3.266)^{\mathrm{a}}$ \\
\hline & & & & 0.618 & 0.249 & 0.798 & $(0.328-1.938)^{b}$ \\
\hline & & & & 0.170 & 1.880 & 1.808 & $(0.769-4.249)^{\mathrm{c}}$ \\
\hline
\end{tabular}

${ }^{\mathrm{a}}$ Comparison between SR \& control, ${ }^{\mathrm{b}}$ Comparison between SS \& control, ${ }^{\mathrm{c}}$ Comparison between SR \& SS

\section{Discussion}

Research in genetics and genome sequencing has led to a better understanding of the molecular genetic mechanisms and to the detection of inter-individual genetic differences, so-called polymorphisms, which may have a functional consequence on the progress of disease and the response to drugs. Angiotensin converting enzymes genotypes (DD/ DI/ II) are traditionally determined using polymerase chain reaction (PCR) amplification according to previously published protocols [13].
$\mathrm{ACE}$ is limiting enzymes participating in the reninangiotensin aldosterone system (RAAS). The RAAS is a hormone that regulates blood pressure and kidney function. The contribution of the RAAS system for hypertension is well documented but the role of RAAS in chronic kidney diseases still remains unclear. However, different types of RAAS blockers like inhibitors of ACE and angiotensin receptor blockers have been suggested to chronic kidney disease patients in order to prevent severe kidney damage [14]. Treatment with RAS inhibitors have been shown to be differing according to the treated individual and not sure to predict responders based on known pathophysiological 


\section{International Journal of Science and Research (IJSR) \\ ISSN (Online): 2319-7064}

Index Copernicus Value (2013): 6.14 | Impact Factor (2015): 6.391

characteristics [15]. Thus different polymorphisms in RAS components especially heterogeneous have been shown to be the major factors to contribute chronic kidney disease involvement [16]. The effect of angiotensin II level is result in renal hemodynamic and causes different growth factors expression, leading to glomerulosclerosis [17]. Moreover, ACE inhibitors and angiotensin receptor blockers reduce proteinuria in patients with nephrotic syndrome [18], stressing the role of the RAAS in the pathogenesis of nephrotic syndrome.

As far as we know, this study provides substantial evidence for the frequency of ACE gene polymorphism using PCR technique in adult Egyptian nephrotic syndrome in relation to steroid resistance and steroid sensitive. The present results revealed a highly significant increase in the presence of D-allele and DD homozygous genotype in steroid resistant patients with idiopathic nephrotic syndrome compared to controls. The D allele has a dominant effect and is associated with higher plasma $\mathrm{ACE}$ and angiotensin II levels [19] - [21]. Our findings are consistent with the previous studies in children demonstrated that the presence of high frequency of DD genotype in steroid resistance nephrotic patients [22], [23]. Similar results were reported that DD genotype has been associated with more severe IgA nephropathy in Japanese children [9] and primary focal segmental glomerulosclerosis in Jewish and Arab children [24]. Lee et al., [25] concluded that DD genotype might be a risk factor for poor response to steroid therapy and the development of chronic renal failure. Also, Prasun et al., [23] found significant higher DD genotype in steroidresistant nephrotic syndrome compared to control or steroidsensitive nephrotic syndrome. Moreover, Langham et al., [5] stated that the increased angiotensin DD genotype may cause steroid resistance through the increased production of nephrin which is a glomerular podocytes slit pore protein and nephrin $\mathrm{N}$ glycosylation at the podocyte.

On the other hand, the frequency of the I allele and the heterozygous of ID genotype was significantly lower in steroid resistance compared to steroid sensitive and control group. These findings are consistent with previous studies by AbdeL-Aziz et al., [26] demonstrated a significant decrease in ACE I/D polymorphism in patients with end stage renal disease. Also, our findings are in agreement with the previous studies reported a significant increase of heterozygous ID genotype in a Lebanese diabetic patients [10]. The authors considered I/D polymorphism as a risk factor for development of Type-2 diabetes mellitus and its complications.

Finally, we observed that the frequency of II genotype was not significantly different between the steroid resistance, steroid sensitive and control groups. The frequency of II genotype has been reported to be less in patients with proteinuria and more prognoses with IgA nephropathy [27]. Both circulating and cellular ACE concentration have been shown to depend on the ACE gene polymorphism, [8], [28]. Also, this polymorphism is reported to be associated in progression of several renal diseases including diabetic nephropathy, polycystic diseases in kidney, and failure in renal transplant recipients.

In conclusion, the present work seems to be the first investigation to be performed in adult patients because the most of previous studied were conducted in children's. The results show that steroid sensitive patients who underwent the disease remission with steroid medication show the same figure like control group. While, steroid resistance patients who underwent cyclosporine medication and without disease remission at the time of sample collection shows an increase in D- allele and DD genotype frequency concomitant with the decrease in I allele and the heterozygous of ID genotype when compared with control healthy individuals or cured nephrotic patients. This result suggests that the D allele or DD homozygous genotype could be significant genetic markers for the development of steroid resistance in adult patients.

\section{References}

[1] Konder C. "Nephrotic Syndrome in Adults: Diagnosis and Management". Am Fam Physician. 80(10):11291134,2009

[2] Long DA, Price KL, Herrera-Acosta J, Johnson RJ. "How does angiotensin II cause renal injury?" Hypertension. 43(4): 722- 3, 2004.

[3] Remuzzi A, Fassi A, Bertani T, Perico N, Remuzzi G. "ACE inhibition induces regression of proteinuria and halts progression of renal damage in a genetic model of progressive nephropathy". Am J Kidney Dis. 34(4): 626- 32, 1999.

[4] Johnston CI, Risvanis J, Naitoh M, Tikkanen I. "Mechanism of progression of renal disease: current hemodynamic concepts". J Hypertens Suppl. 16(4): S37, 1998.

[5] Langham RG, Kelly DJ, Cox AJ, Gow RM, Holthofer $\mathrm{H}$, Gilbert RE. "Angiotensin II-induced proteinuria and expression of the podocyte slit pore membrane protein, nephrin". Nephrol Dial Transplant. 19(1): 262- 3, 2004.

[6] Eisenbach GM, Van Liew JB. "Effect of angiotensin on glomerular filtration of albumin". Contrib Nephrol. 1: 28-36, 1975.

[7] Korbet SM. "Angiotensin antagonists and steroids in the treatment of focal segmental glomerulosclerosis". SeminNephrol. 23(2): 219- 228, 2003.

[8] Rigat, B, Hubert, C, Alhenc-Gelas, F, Cambien, F, Corvol P, Soubrier, F. "An insertion/deletion polymorphism in the angiotensin I-converting enzymegene accounting for half the variance of serum enzyme levels". J Clin Invest. 86: 1343- 6, 1990.

[9] Maruyama K, Yoshida M, Nishio H, Shirakawa T, Kawamura T, Tanaka R, Nakamura H, Iijima K, Yoshikawa N. "Polymorphisms of renin-angiotensin system genes in childhood IgA nephropathy". Pediatr Nephrol. 16(4): 350- 5, 2001.

[10] Chmaisse HN, Jammal M, Fakhoury H, Fakhoury R. "A study on the association between angiotensin-I converting enzyme I/D dimorphism and type-2 diabetes mellitus". Saudi J Kidney Dis Transpl; 20(6): 1038- 46, 2009. 


\section{International Journal of Science and Research (IJSR) \\ ISSN (Online): 2319-7064}

Index Copernicus Value (2013): 6.14 | Impact Factor (2015): 6.391

[11] Aucella F, Vigilante M, Margaglione M, Grandone E, del Popolo A, Forcella M, Procaccini D, Salatino G, Passione A, Ktena M, De Min A, Stallone C. "Polymorphism of the angiotensin-converting enzyme gene in end-stage renal failure patients". Nephron. 85(1): 54- 9, 2000.

[12] Pérez-Oller L ${ }^{1}$, Torra R, Badenas C, Milà M, Darnell A. "Influence of the ACE gene polymorphism in the progression of renal failure in autosomal dominant polycystic kidney disease". Am J Kidney Dis. 34(2): 273- 8, 1999.

[13] Rigat B, Hubert C, Corvol P, Soubrier F. "PCR detection of the insertion/deletion polymorphism of the human angiotensin converting enzyme gene (DCP1) (dipeptidylcarboxypeptidase 1)". Nucleic Acids Res. 20(6): 1433, 1992.

[14] Mondry A, Loh M, Liu P, Zhu AL, Nagel M. "Polymorphisms of the insertion / deletion ACE and M235T AGT genes and hypertension: surprising new findings and meta-analysis of data". BMC Nephrol. 6: 1,2005

[15] Mayer G. "ACE genotype and ACE inhibitor response in kidney disease: a perspective". Am J Kidney Dis. 40(2): 227-35, 2002.

[16] Tripathi G, Dharmani P, Khan F, Sharma RK, Pandirikkal V, Agrawal S. "High prevalence of ACE DD genotype among north Indian end stage renal disease patients". BMC Nephrol. 7:15, 2006.

[17] Oktem, F, Sirin, A, Bilge, I, Emre, Agachan, B, Ispir T. "ACE I/D gene polymorphism in primaryFSGS steroidsensitive nephrotic syndrome". Pediatr Nephrol; 19:384-9, 2004.

[18] White, CT, Macpherson, CF, Hurlet,RM, Matsell,DG "Antiproteinuric effects of enalapril and losartan: a pilot study". Pediatr Nephrol; 18:1038-43, 2003.

[19] Bagga, A. Srivastava, RN. "Nephrotic syndrome and proteinuria". Indian J Pediatr; 69:1053- 4, 2002.

[20]Ribichini, F, Steffenino, G, Dellavalle, A. "Plasma activityand insertion/deletion polymorphism of angiotensinI-converting enzyme, a major risk factor and a marker of risk for coronary stent restenosis". Circulation. 97:147 -54, 1998.

[21] Cambien F, Poirier O, Lecerf L, Evans A, Cambou JP, Arveiler D, Luc G, Bard JM, Bara L, Ricard S, et al. "Deletion polymorphism in the gene for angiotensinconverting enzyme is a potent risk factor for myocardial infarction". Nature. 359 (6396): 641-4, 1992.

[22] Patil SJ, Gulati S, Khan F, Tripathi M, Ahmed M, Agrawal S. "Angiotensin converting enzyme gene polymorphism in Indian children with steroid sensitive nephrotic syndrome". Indian J Med Sci. 59(10): 431- 5, 2005.

[23] Prasun P, Prasad N, Tripathi G, Jafar T, Sharda S, Gulati S, Agrawal S. "Association of angiotensinconverting enzyme gene I/D polymorphism with steroid responsiveness in childhood nephroticsyndrome". Indian J Nephrol. 21(1): 26-9, 2011.

[24] Frishberg Y, Becker-Cohen R, Halle D, Feigin E, Eisenstein B, Halevy R, Lotan D, Juabeh I, Ish-Shalom N, Magen D, Shvil Y, Sinai-Treiman L, Drukker A. "Genetic polymorphisms of the renin-angiotensin system and the outcome of focal segmental glomerulosclerosis in children". Kidney Int. 54(6):1843-9, 1998

[25] Lee DY, Kim W, Kang SK, Koh GY, Park SK. "Angiotensin-converting enzyme gene polymorphism in patients with minimal-change nephrotic syndrome and focal segmental glomerulosclerosis". Nephron. 77(4):471-3, 1997.

[26] AbdeL-Aziz1, AF, EL-Saeed, F, EL-Dahshan, K and Ebead, BA. "Association of Angiotensin-I-Converting Enzyme (ACE) Insertion/Deletion Gene Polymorphism with End Stage Renal Disease in Egyptian Patients". British Journal of Medicine \& Medical Research 4(8) 1763-1771, 2014.

[27] Syrjänen J, Huang XH, Mustonen J, Koivula T, Lehtimäki T, Pasternack A. "Angiotensin-converting enzyme insertion/deletion polymorphism and prognosis of IgA nephropathy". Nephron. 86(2): 115-21, 2000.

[28] Costerousse, O, Alledgrini, J, Lopez, M, Alhenc-Gelas, F. "Angiotensin I converting enzyme in human circulating mononuclear cells: genetic polymorphism of expression in T-lymphocytes". Biochem J; 290:33-40, 1993. 